\title{
High Income Inequality as a Structural Factor in Entrepreneurial Activity
}

\author{
Antonio Lecuna'
}

\begin{abstract}
Statistical tests on a panel of data from 54 countries over the 2004-2009 period support the proposition that high income inequality and entrepreneurial activity share a positive linear relationship. In a novel approach, the dependent variable is defined from two independent and uncorrelated perspectives: (I) the World Bank Group Entrepreneurship Snapshot, which measures new business entry density based on secondary official sources; and (2) the Total Early Stage Entrepreneurial Activity of the Global Entrepreneurship Monitor project, which is a survey-based measure of formal and informal entrepreneurial participation rates. The empirical strategy is based on the logic that economies with increasing concentrations of wealth tend to encourage entrepreneurial activity because entrepreneurs accumulate more income than workers. Following the disequalizing model, once this inequality appears, it is reinforced in successive generations. The intuition behind this outcome is that a certain level of initial capital is required to establish a new enterprise, which implies that the probability of becoming an entrepreneur increases if an individual has inherited wealth.
\end{abstract}

Keywords: entrepreneurial activity; income inequality; institutions; gini index.

\footnotetext{
'Universidad del Desarrollo (Chile).Ave. La Plaza 680, Las Condes, Santiago, Chile. Phone: +(56 2) 3273777 e-mail: alecuna@udd.cl. An approximation of the findings titled "Is high-income inequality the price that has to be paid to foster entrepreneurship?" was presented at the 8th Iberoamerican Academy Conference held in December 2013 in São Paulo. Comments from professor José Ernesto Amorós are included in this final version.
}

ISSN: 07 I8-2724. (http://www.jotmi.org) 


\section{Introduction}

The widening development gap among countries is an omnipresent and well-documented trend (Kreutzmann, 2008). Approximately $80 \%$ of the world's total gross domestic product (GDP) belongs to the I billion people living in developed countries, and the remaining $20 \%$ is shared by the 5 billion people living in the developing world. The vast majority of the world's population is poor. This concentration of wealth is a puzzle that has not yet been adequately solved in the management literature. In fact, the relationship between business creation and wealth remains one of the most understudied and important issues in the growing field of entrepreneurship (Fairlie and Krashinsky, 20I2).

The general objective of this paper is to bridge two subdisciplines in the respective fields of management and economics: entrepreneurship and development economics. According to Naudé (2010), entrepreneurship and development economics have evolved in relative isolation with respect to one another; because development economics is the sub-discipline in economics that addresses growth and structural change in economies, this gap is a surprising limitation in the academic literature. Bapuji and Riaz (2013) add that management literature requires more empirical work that addresses the linkages between economic inequality and management, rather than focusing solely on either one in isolation.

This paper takes a small step toward understanding the origins of entrepreneurial activity by investigating the extent to which income inequality is a determining factor; specifically, it asks whether inequalities in income distribution play an important role in fostering entrepreneurial activity. I draw on panel data from 54 nations for the period 2004-2009 to test the proposition that the level of income inequality affects the rates of entrepreneurial activity across nations. Based on cross-country statistical analyses of such panel data, I posit that a rise in income inequality increases the probability of entrepreneurial activity. As a novel approach, I use two indicators for entrepreneurial activity as dependent variables, each of which reflects a different aspect of entrepreneurship.

The results indicate that there is a positive linear relationship among income inequality and the following two independent measures of entrepreneurial activity across nations: (I) entry density, as derived from the World Bank Group Entrepreneurship Snapshot (WBGES); and (2) Total Early Stage Entrepreneurial Activity (TEA), as derived from the Global Entrepreneurship Monitor (GEM) project. The results are robust to a wide range of macroeconomic, institutional, and competitiveness controls.
Entrepreneurs accumulate more income than workers, which leads to concentrations of wealth (Quadrini, 1999), and also have higher wealth-income ratios and higher saving rates than workers. These different saving patterns generate higher asset holdings and higher levels of wealth concentration in the hands of entrepreneurs (Meh, 2005). Moreover, previous generations of wealthier families are more likely to be characterized by individuals who have engaged in entrepreneurial activities than the previous generations of other families; thus, because the wealth accumulated during business periods is generally not depleted immediately, these entrepreneurial families have greater resources to start or restart businesses (Quadrini, 1999). These features of the family dynamics of entrepreneurs further reinforce the intuition that the probability of becoming an entrepreneur increases if an individual has inherited wealth because initial capital is required to establish new enterprises (Holtz-Eakin et al., 1994a; 1994b).

The findings of this paper complement the arguments of Shane (2009) that the typical start-up is not innovative, generates little wealth, does not make markets more competitive, and creates few jobs. Shane (2009) adds that government resources are founding wage-substitution businesses that have more in common with self-employment than with the creation of high-growth start-ups. The practical implications of the findings are grounded in the conceptual framework that self-employed individuals at the lower end of the distribution are fundamentally different from the selfemployed individuals at the upper end of the distribution (Tamvada, 2010). Therefore, "entrepreneurship-supporting policies could be particularly successful in reducing inequality if directed at the low-income, low-wealth, and relatively uneducated segments of society" (Kimhi, 2010: 89).

The rest of the article is structured as follows. The next section presents the theoretical arguments related to the relationship between entrepreneurial activity and income inequality. I then provide a description of the variables of interest and the sample selection. Next, I define the structural factors in entrepreneurial activity and describe a series of statistical tests together with their most significant findings. The last section concludes with a discussion and suggestions for future research, in addition to addressing the main limitations of the study.

\section{Theoretical framework}

Entrepreneurial activity is frequently considered a key source of jobs (Bednarzik, 2000) and economic growth (Schumpeter, 1934), even during economic crisis (Kraus et al., 20I2). However, despite the growing list of beneficial consequences, entrepreneurial activity should not be considered an umbrella policy, mainly because entrepreneurship 
might also be linked to wealth accumulation and distribution (Holtz-Eakin et al., 1994a, 1994b; Quadrini, 1999; Gentry and Hubbard, 1999; Meh, 2005).

In this study, I contribute to the argument that links entrepreneurial activity and income inequality by using data in the statistical tests that cover a larger sample (54 countries) and a more recent period (from 2004 to 2009) than the previous literature. Measuring entrepreneurial activity as the dependent variable from two independent and uncorrelated perspectives is also a novel approach compared with the previous literature.

\section{Disequalizing Model}

Three models have essentially tried to explain patterns of income inequality. The neutral model suggests that societies that begin equal remain equal over the long run. Thus, variations in the level of development across countries can be explained by historical differences in inequality (Galor and Zeira, 1993; Ghatak and Jiang, 2002). The equalizing model predicts that wealth differences among households tend to vanish over the long run because market forces offer a variety of investment options (Becker and Tomes, 1979; Loury, 198I). In contrast, the disequalizing model argues that, even if all households begin equally, the children of such households must choose occupations that have varying entry costs, which results in inequality for the following generation (Ljungqvist, 1993); once this inequality appears, it tends to be reinforced in successive generations (Freeman, 1996). The conceptual framework of this paper is based on the disequalizing model because entrepreneurs tend to accumulate more income than workers, which encourages concentrations of wealth among entrepreneurs that are difficult to reverse. The logic is straightforward. The higher targeted wealth-income ratio leads to higher saving rates among enterprising households compared with worker households. The different saving patterns of entrepreneurs and workers in turn result in higher asset holdings and a higher level of concentration in the entire distribution of wealth for entrepreneurs (Meh, 2005: 707). Tamvada (2010) also found patterns of an unequal distribution of income among entrepreneurs because those individuals who also hire others have the highest returns in terms of consumption, whereas the self-employed, i.e., those entrepreneurs who work for themselves, have slightly lower returns than salaried employees.

\section{Liquidity Constraint Argument}

Empirical work on the impact of liquidity constraints on the decision to become an entrepreneur is grounded in the argument that initial capital is typically required to establish a new enterprise; thus, the probability of becoming an entrepreneur increases if an individual has inherited wealth. Us- ing data from the $198 \mathrm{I}$ and 1985 federal individual income tax returns of a group of people who received inheritances in 1982 and 1983 that includes information about the size of their inheritances, Holtz-Eakin et al. (1994a) found that an inheritance of $\$ 150,000$ increases the probability that an individual will continue as a sole proprietor by 1.3 percentage points and that the receipts of any surviving enterprise increase by almost $20 \%$. Similarly, Holtz-Eakin et al. (1994b) suggest that a $\$ 100,000$ inheritance increases the probability of making the transition to entrepreneurship from $19.3 \%$ to $22.6 \%$, or 3.3 percentage points.

Quadrini (1999) reached similar conclusions: in wealthier families, individuals who have engaged in business activities during previous periods are more common than those who have not, and these families have greater resources to restart businesses because the wealth accumulated during the business period is generally not depleted immediately. Using family wealth data for the years 1984 and 1989 from the Panel Study of Income Dynamics (an annual national survey conducted since 1968 on a sample of more than 4,800 U.S. families), Quadrini (1999) concludes that owning a business can only be partially financed with external funds, such that only those with sufficient personal wealth are able to found profitable businesses. These findings support Blanchflower and Oswald (1990), who suggest that if owning a substantial capital stock is important to starting a business, then those who receive a lump sum of capital should have a higher probability of success.

Ultimately, because of liquidity constraints, only those entrepreneurs who have substantial personal financial resources will survive and grow in the medium to long run because the average entrepreneur cannot borrow sufficiently to attain profit-maximizing levels of capital (Holtz-Eakin et al., 1994a). This intuition is consistent with empirical regularities of firm size dynamics: smaller firms fail more often than large firms. Firms in fact become larger because their exit rates are lower (Meh, 2005); thus, the larger the project, the lower its probability of receiving bad shocks. Based mainly on these arguments, I therefore hypothesize that a rise in income inequality increases the probability of entrepreneurial activity.

\section{Data definition and sample selection}

\section{Dependent Variables}

The measure for the first dependent variable (i.e., entrepreneurial activity) is from the 2010 dataset of the WBGES. The WBGES uses new business entry density to measure entrepreneurial activity. This measure is calculated as the number of newly registered firms as a percentage of the economy's working-age population ( $15-64$ years of age) normalized by I,000 for the six-year period from 2004 through 2009 (Klap- 
per and Love, 2010; World Bank, 2010). The second dependent variable comes from the GEM project's TEA measurement.TEA is the participation rate of working-age individuals in the early stages of venture creation (Amorós, 20l I). This "early stage" work includes "nascent entrepreneurship," the stage that occurs before a new firm is opened, and "owning-managing a new firm," which includes an additional 42 months after the start-up date (Bosma et al., 2012: 20).

Although business registration is an official record and the TEA rate is an estimate that is based on phone surveys, using TEA has advantages because it focuses on the person and on both formal and informal work (Amorós, 20II). Unregistered firms that belong to the informal sectors of the economy in fact may comprise as much as $80 \%$ of the economic activity in developing countries (Bosma et al., 20I2). Thus, including informal entrepreneurship in the measurement of entrepreneurial activity should generate more accurate results. Moreover, as has been argued elsewhere (Hinojosa-Martínez and Albornoz-Pardo, 2013; CabanaVillca et al., 2013), GEM data is a sufficiently valid empirical source of information.

\section{Main independent variable}

The focal point of the analysis is income inequality, which can be measured accurately by the Gini index, which is a scale that measures the degree of inequality in a country's income distribution. The more equal a country's income distribution is, the lower its Gini index, whereas the more unequal a country's income distribution is, the higher its Gini index. If income is distributed with perfect equality, the index value is zero; if income is distributed with perfect inequality, the index value is 100 .

Three secondary sources of information were used as measurements for the Gini index: the Central Intelligence Agency World Factbook (CIA - The World Factbook), the United Nations Development Programme indicators (UNDP), and the United Nations University World Institute for Development Economics Research income inequality database (UNU-WIDER). The definition and methodology for calculating the Gini index are practically identical in these three sources. In cases in which data were available from more than two sources, the average for that period was used (Refer to Table AI in the appendix.)

\section{Sample}

The sampling technique is probability systematic, in which the initial sampling point is selected at random and the cases are then selected at regular intervals. The initial sampling point is the WBGES dataset of 115 developing and industrial countries for the 2004-2009 period. In the analysis, the world sample was first trimmed to 62 countries and included only those countries that appeared in both the GEM and the WBGES dataset during the 2004-2009 period. The second cut was made because of a lack of data for six countries once the macroeconomic variables included in the World Economic Outlook (WEO) database were used (these variables are defined in the regression models as "basic effects"). These six countries include the following: Bolivia, Guatemala, India, and Uganda (lack of unemployment data); Macedonia (lack of investment data); and Switzerland (lack of savings data).The next cut (Tunisia) reduced the sample to 55 countries and was made to conform to the use of data from the Global Competitiveness Index $(\mathrm{GCl})$. The final sample number of 54 countries (shown in Table A2 in the appendix) was arrived at by eliminating Algeria, for which data required to calculate the Gini coefficient were missing.

\section{Structural factors in entrepreneurial activity}

Three sources of information are used to measure the structural factors in entrepreneurial activity: the WEO database from the International Monetary Fund, the Worldwide Governance Indicators (WGIs) from the World Bank, and the $\mathrm{GCl}$ from the World Economic Forum, Executive Opinion Survey Dataset. (Table I at the end of this section presents the descriptive statistics of all variables.)

\section{World Economic Outlook (WEO)}

The values for the 2004-2009 period from the April 2012 WEO database are used to measure four basic effect factors. The first three factors are expected to demonstrate a positive relationship with both measures of entrepreneurial activity (i.e., WBGES and TEA), whereas the unemployment rate is expected to have a strong negative sign (Bednarzik, 2000).

I. Log GDP per capita: Data are derived by first converting GDPs in their national currencies to U.S. dollars and then dividing by the total applicable population. GDP per capita is expressed using logs to avoid giving excessive weight to extremely high and low observations.

2. Investment rate: This factor is expressed as the ratio of total investment in the current local currency to GDP in the current local currency. Total investment, or gross capital formation, is the total value of the gross fixed capital formation, changes in inventories, and acquisitions, less the disposal of valuables for a unit or sector.

3. Savings rate:This factor is expressed as the ratio of gross national savings in the current local currency to GDP in the current local currency. Gross national savings is gross disposable income less final consumption expenditures after taking into account an adjustment for pension funds. 
4. Unemployment rate:The unemployment rate is expressed as the percentage of unemployed workers in the total labor force. As defined by the International Labour Organization, unemployed workers are those who are currently not working but are willing and able to work for pay and are actively searching for work.

\section{Worldwide Governance Indicators}

According to the Organisation for Economic Co-operation and Development (OECD) (1998), institutions are essential for understanding the outcomes observed in entrepreneurship, where institutions are broadly understood as the "rules of the game" (Naudé, 20I0: I). However, measuring the umbrella term "institutions" is a difficult task. I used three WGls for the period 2004-2009. These variables are expected to have strong positive coefficients. (WGI scores range from approximately -2.5 to 2.5 , with higher values corresponding to better levels of governance.)

I.Voice and accountability: This variable reflects perceptions about the extent to which a country's citizens are able to participate in selecting their government and to exercise rights involving freedom of expression, freedom of association, and a free media.

2. Political stability and the absence of violence:This variable reflects perceptions of the likelihood that the government will be destabilized or overthrown by unconstitutional or violent means, which includes politically motivated violence and terrorism.
3. Rule of law:This variable reflects perceptions of the extent to which agents have confidence in and abide by the rules of society, particularly with respect to the quality of contract enforcement, property rights, the police, and the courts, in addition to the likelihood of crime and violence.

\section{Global Competitiveness Index}

The OECD (1998) report also includes other competitiveness issues as potential factors of entrepreneurial activity, such as the quality of infrastructure and the availability of venture capital. These factors are measured effectively using the $\mathrm{GCls}$ (the $\mathrm{GCl}$ scores are expressed on a scale ranging from I to 7 , with 7 being the most desirable outcome). The GCls, however, are available only for the 2006-2009 period. All $\mathrm{GCl}$ variables are expected to have a strong positive coefficient except for the number of procedures and days required to start a business.

I.Venture capital availability. This indicator asks, "How easy is it for entrepreneurs with innovative but risky projects to find venture capital?" [ 1 = very difficult; 7 = very easy].

2. Quality of the educational system. This indicator asks, "How well does the educational system in your country meet the needs of a competitive economy?" [I = not well at all; 7 = very well].

3. Property rights. This indicator asks, "How would you rate the protection of property rights, including financial assets, in your country?" [I = very weak; 7 = very strong].

\begin{tabular}{lccccc}
\hline & $\begin{array}{c}\text { Observa- } \\
\text { tions }\end{array}$ & Mean & $\begin{array}{c}\text { Standard } \\
\text { Deviation }\end{array}$ & Minimum & Maximum \\
\hline Entrepreneurship Snapshots (WBGES) & 298 & 3.82 & 4.29 & 0.09 & 27.03 \\
Total Entrepreneurial Activity (TEA) & 208 & $8.7 \%$ & $6.1 \%$ & $1 \%$ & $40 \%$ \\
GINI index & 185 & 38.07 & 10.49 & 23 & 67.4 \\
Log GDP per capita & 324 & 4.10 & 0.48 & 3.04 & 4.98 \\
Investment rate & 324 & $23.1 \%$ & $4.6 \%$ & $14 \%$ & $40 \%$ \\
Savings rate & 324 & $22.1 \%$ & $7.3 \%$ & $-4 \%$ & $48 \%$ \\
Unemployment rate & 324 & $8.5 \%$ & $5.1 \%$ & $1 \%$ & $31 \%$ \\
Voice \& accountability & 324 & 0.64 & 0.77 & -1.22 & 1.83 \\
Political stability \& absence of violence & 324 & 0.24 & 0.85 & -2.20 & 1.59 \\
Rule of law & 324 & 0.63 & 0.94 & -1.03 & 2.01 \\
Venture capital availability & 215 & 3.56 & 0.85 & 1.96 & 5.38 \\
Quality of overall infrastructure & 215 & 4.55 & 1.29 & 1.97 & 6.70 \\
Property Rights & 215 & 5.13 & 1.03 & 2.78 & 6.67 \\
\hline
\end{tabular}

Table I. Descriptive Statistics

ISSN: 07 I8-2724. (http://www.jotmi.org) 


\section{Empirical tests and results}

Between-effects (BE) models with the ordinary least squares (OLS) option are used in all the specifications. Because the $\mathrm{p}$-value of the Hausman test is not significant, the choice of fixed-effects models is rejected. BE models estimate the cross-sectional information in the data, the fixed-effects models use the time-series information in the data, and the random-effects estimator is a matrix-weighted average of the results from these two models. BE models fit "random- effects models by using the between-regression estimator" (StataCorp, 2009:442). Regressions with between effects are equivalent to taking the mean of each variable for each case across time and running a regression on the collapsed dataset of the means. The BE model should be used to control for omitted variables that change over time but are constant between cases. This characteristic is typical for crosscountry estimates that explain entrepreneurial activity using both the individual and combined effects of macroeconomic factors, institutional factors, and competitiveness factors. In

\begin{tabular}{|c|c|c|c|c|c|c|}
\hline \multirow[t]{2}{*}{$\begin{array}{l}\text { Dependent Variables: } \\
\text { WBGES \& TEA }\end{array}$} & \multicolumn{2}{|c|}{$\begin{array}{l}\text { Macroeconomic } \\
\text { basic effect }\end{array}$} & \multicolumn{2}{|c|}{$\begin{array}{l}\text { Basic effect + institu- } \\
\text { tional indicators }\end{array}$} & \multicolumn{2}{|c|}{$\begin{array}{c}\text { III } \\
\text { Whole-set (including } \\
\text { competitevenes indi- } \\
\text { cators) }\end{array}$} \\
\hline & WBGES & TEA & WBGES & TEA & WBGES & TEA \\
\hline GINI index & $\begin{array}{c}0.11 \\
(1.78)^{*}\end{array}$ & $\begin{array}{c}0.002 \\
(1.78)^{*}\end{array}$ & $\begin{array}{c}0.14 \\
(2.26)^{\star *}\end{array}$ & $\begin{array}{c}0.001 \\
(1.71)^{*}\end{array}$ & $\begin{array}{c}0.15 \\
(3.11)^{* * *}\end{array}$ & $\begin{array}{c}0.002 \\
(1.78)^{*}\end{array}$ \\
\hline Log GDP per capita & $\begin{array}{c}4.26 \\
(2.97)^{\star * *}\end{array}$ & $\begin{array}{c}-0.07 \\
(-3.06)^{\star * *}\end{array}$ & $\begin{array}{l}0.59 \\
(0.24)\end{array}$ & $\begin{array}{c}-0.12 \\
(-3.29)^{\star * *}\end{array}$ & $\begin{array}{c}2.56 \\
(1.38)\end{array}$ & $\begin{array}{c}-0.11 \\
(-2.92)^{\star * *}\end{array}$ \\
\hline Investment rate & $\begin{array}{l}18.68 \\
(1.55)\end{array}$ & $\begin{array}{l}-0.017 \\
(-0.11)\end{array}$ & $\begin{array}{l}15.75 \\
(1.31)\end{array}$ & $\begin{array}{c}0.08 \\
(0.47)\end{array}$ & $\begin{array}{c}20.45 \\
(2.60)^{\star \star}\end{array}$ & $\begin{array}{r}0.09 \\
-0.56\end{array}$ \\
\hline Savings rate & $\begin{array}{c}-19.86 \\
(-2.24)^{\star *}\end{array}$ & $\begin{array}{l}-0.19 \\
(-1.34)\end{array}$ & $\begin{array}{c}-25.19 \\
(-2.60)^{* *}\end{array}$ & $\begin{array}{l}-0.06 \\
(-0.37)\end{array}$ & $\begin{array}{c}-22.28 \\
(-3.38)^{\star \star *}\end{array}$ & $\begin{array}{l}-0.06 \\
(-0.41)\end{array}$ \\
\hline Unemployment rate & $\begin{array}{c}-40.19 \\
(-2.54)^{\star *}\end{array}$ & $\begin{array}{c}-0.41 \\
(-2.02)^{*}\end{array}$ & $\begin{array}{c}-39.86 \\
(-2.60)^{\star *}\end{array}$ & $\begin{array}{c}-0.43 \\
(-2.09)^{\star *}\end{array}$ & $\begin{array}{l}-23.32 \\
(-2.02)^{\star}\end{array}$ & $\begin{array}{l}-0.36 \\
(-1.61)\end{array}$ \\
\hline Voice \& accountability & & & $\begin{array}{l}-1.11 \\
(-0.85)\end{array}$ & $\begin{array}{c}0.04 \\
(1.74)^{*}\end{array}$ & $\begin{array}{c}-1.80 \\
(-1.87)^{\star}\end{array}$ & $\begin{array}{c}0.03 \\
(1.53)\end{array}$ \\
\hline Political stability \& absence of violence & & & $\begin{array}{c}1.46 \\
(1.49)\end{array}$ & $\begin{array}{l}-0.01 \\
(-1.06)\end{array}$ & $\begin{array}{c}1.08 \\
(1.52)\end{array}$ & $\begin{array}{l}-0.01 \\
(-0.79)\end{array}$ \\
\hline Rule of law & & & $\begin{array}{c}2.01 \\
(1.70)^{\star}\end{array}$ & $\begin{array}{l}0.01 \\
(0.45)\end{array}$ & $\begin{array}{c}1.86 \\
(1.13)\end{array}$ & $\begin{array}{c}0.01 \\
(0.23)\end{array}$ \\
\hline Venture capital availability & & & & & $\begin{array}{c}2.26 \\
(2.80)^{\star \star \star}\end{array}$ & $\begin{array}{c}0.02 \\
(1.02)\end{array}$ \\
\hline Quality of overall infrastructure & & & & & $\begin{array}{l}-0.13 \\
(-0.18)\end{array}$ & $\begin{array}{l}-0.004 \\
(-0.29)\end{array}$ \\
\hline Property rights & & & & & $\begin{array}{l}-1.55 \\
(-1.27)\end{array}$ & $\begin{array}{l}-0.01 \\
(-0.48)\end{array}$ \\
\hline Adjusted $R$-squared & $35 \%$ & $42 \%$ & $45 \%$ & $48 \%$ & $62 \%$ & $53 \%$ \\
\hline$N$ & 171 & 129 & 171 & 129 & 102 & 83 \\
\hline
\end{tabular}

Table 2. Cross-country results for entrepreneurial activity, panel data 2004-2009. (Between-estimates linear regression models, OLS) Notes: Heteroskedasticity-consistent t-ratios (White, 1980) in parentheses.

*** Significant at $1 \%$; **significant at $5 \%$; *significant at $10 \%$.

ISSN: 07 I8-2724. (http://www.jotmi.org)

Journal of Technology Management \& Innovation (c) Universidad Alberto Hurtado, Facultad de Economía y Negocios. 
particular, $\mathrm{BE}$ models use the variation among countries to estimate the effect of the omitted independent variables on the two measurements of entrepreneurial activity. In all the specifications, the $B E$ models are consistent because the panel-level means of the regressors are uncorrelated with the panel-specific heterogeneity terms.

Table 2 shows that three factors are clearly the most significant. The first is that entrepreneurial activity is consistently associated with more income inequality. The estimated coefficients of the income inequality regressor are always significant, assuming that classical assumptions hold. However, the slope coefficients are relatively small, which implies that an improvement (i.e., decrease) in the Gini index score of approximately six units is associated with a decrease in the registration of approximately one new firm for every 1,000 working-age adults and with an approximately I percentage point decrease in the number of working-age individuals who engage in some type of entrepreneurial activity (assuming that all other factors affecting entrepreneurial activity are held constant). Statistically speaking, the explanatory power of income inequality regarding entrepreneurial activity is reasonably good as judged by the usual t-test of significance. In all statistical tests, I compute robust standard errors for which I correct for potential heteroskedasticity and for the potential correlation of the error term across observations.' The negative estimator of the parameter in the TEA speci-fications, however, does not confirm the underlying theory, but this result should not be surprising. In fact, a growing stream of research has documented a negative relationship between entrepreneurial activity and economic growth in developing countries (Van Stel et al., 2005). One explana-tion for this negative relationship is that the TEA meas-urement captures both formally and informally registered businesses (Bosma et al., 2012). Another explanation is that entrepreneurial activity has two drivers (Acs and Amorós, 2008; Amorós and Cristi, 2008). The first is necessity-driven entrepreneurship, which is common in poor countries. The second is opportunitydriven entrepreneurship, which is common in wealthy countries.

The third significant factor in terms of significance, the unemployment rate, supports the underlying theory (Bednarzik, 2000). As predicted, the WBGES specifications indicate that if the unemployment rate decreases by I percentage point, the median number of newly registered firms per 1,000 working-age individuals increases by approximately 4 on average (significant at the $5-10 \%$ level). The TEA specifications support these findings; that is, a decrease in the unemployment rate by I percentage point, ceteris paribus, is associated with an increase of less than half a percentage point in the average number of working-age adults who engage in entrepreneurial behavior. However, it is also notable that after the competitiveness indicators entered the regression, the unemployment rate in the TEA specification lost significance, which is a typical sign of multicollinearity issues. These signs of multicollinearity are similar to the effect observed with log GDP per capita once the institutional indicators entered the WBGES specifications.

In fact, estimating an individual joint relationship between entrepreneurial activity and its determining factors is not free of a potentially high degree of multicollinearity among explanatory variables. The first signs of multicollinearity are high pairwise correlations (shown in Table A3 in the appendix). Pairwise correlations between explanatory variables are relatively low except for log GDP per capita. More importantly, the low correlations between the Gini index and the other predictors might suggest that multicollinearity is most likely not a problem for the main variable of interest. However, in the strictest sense, high pairwise correlations among explanatory variables are frequently unreliable and misleading, "for pairwise correlations can be low (suggesting no serious collinearity problems) yet collinearity is suspected because very few $t$ ratios are statistically significant" (Guratti and Porter, 2010: 254-255).

As an alternative to simple pairwise correlations, a few indicators signal the existence of multicollinearity in concrete applications. For example, the main variable of interest-the Gini index-generates very small changes in the estimated regression coefficients when the institutional and competitiveness predictor variables are added. Moreover, I also used the variance inflation factor (VIF) for the entire dataset as an indicator of multicollinearity. The VIF values ranged from the two lowest, I.33 (investment rate) and I.76 (unemployment rate), to the two highest, 17.89 (rule of law) and 10.30 (property rights). In theory, when the VIF value is less than 10 , multicollinearity is not a problem. The VIF cutoff value of 10 was originally suggested by Marquardt (1970, p. 610) and was later validated by Marquardt (1987), O'Brien (2007), and Mason and Perreault (199|). Once the two problematic variables - "rule of law" and "property rights"-were dropped from the equation, the mean VIF decreases from 5.34 to 2.64 (Gini index VIF scores decreased from 2.32 to I.77).

Finally, I also ran several regressions that always included the Gini index, but I omitted explanatory variables with relatively high degrees of collinearity. In this way, I marginally controlled for plausible scenarios in which the main inde-

\footnotetext{
'Interpretations of the empirical results follow the principle of Ock-ham's razor to maintain simplicity in the explanations. William Ock-ham (1285-1349) argues that a complicated explanation should not be accepted without good reason and writes as follows: "Frustra fit per plura, quod fieri potest per pauciora - It is vain to do with more what can be done with less" (Gujarati and Porter, 20I0: 27).
} 
pendent variable might capture the explanatory power of similar predictors. In all cases, the Gini index had strong and significant positive coefficients in the regression models. For example, the first two columns of Table A4, which test multicollinearity issues after dropping "rule of law" and "property rights," are plausibly the most robust models, which results mainly because the significance is more evenly distributed among explanatory variables and the overall fits of the models report values as high as $73 \%$.

Although it is possible to alleviate (but never eliminate) potential endogeneity between entrepreneurial activity and its explanatory factors, the last two columns of Table A4 address issues of endogeneity by lagging all explanatory variables one year. It is important to note that the endogeneity tests do not affect the size or direction of the coefficients. Endogeneity tests, however, decrease the number of observations, which affects the validity of the results, i.e., regarding the TEA specifications. Table A4 also confirms venture capital availability as a significant determining factor of entrepreneurial activity, which is logical.

\section{Conclusion}

Contrary to the mainstream literature that associates entrepreneurial activity to overall well-being, this paper specifically suggests that entrepreneurial activity is associated with greater income inequality (within the limitation of a world sample of 54 countries). Following the disequalizing model, which predicts that income inequality is reinforced over successive generations (Freeman, 1996), the arguments to support these findings are based on the logic that entrepreneurs tend to accumulate more income than workers, which leads to concentrations of wealth among entrepreneurs (Quadrini, 1999). Enterprising households also have a higher wealth-income ratio than workers and thus have higher saving rates, which leads to higher asset holding in the hands of entrepreneurs (Meh, 2005). A higher concentration of wealth and higher asset holding, in turn, increases the probability among enterprising families of receiving inherited wealth (Holtz-Eakin et al., 1994a; 1994b). In addition, those individuals who receive a lump sum of capital should have a higher probability of becoming successful entrepreneurs because owning a stock of capital is important to starting a business (Blanchflower and Oswald, 1990).

The conclusions presented here are subject to a number of limitations. First, the Gini coefficients for different countries are sometimes calculated using different methods. Some coefficients are calculated using expenditures, whereas others use revenues (Alesina, Di Tella, MacCulloch, 2004: 20I32014). Furthermore, the measurements of the two dependent variables might also be misleading because data based on the registration of firms are dubious in highly corrupt countries and also because the GEM data might present bias issues due to their collection from phone surveys. Another limitation of studying income inequality and entrepreneurial activity is that there might be a problem of reverse causality. For example, individuals may have a higher tendency to report themselves as entrepreneurs out of sheer necessity when inequality is high because there are no jobs available in the economy.

An interesting extension of the findings presented here would be to study the specific conditions required to reverse the association between income inequality and entrepreneurial activity. One research opportunity is to qualitatively explore specific cases in which fostering high-growth entrepreneurship is accompanied by a positive impact on income inequality. Shane (2009) specifically argues that it is good public policy to stop subsidizing the formation of the typical start-up and instead to focus on the subset of businesses with growth potential. Kimhi (2010:89) also suggested, "entrepreneurship-supporting policies could be particularly successful in reducing inequality if directed at the low-income, low-wealth, and relatively uneducated segments of society." These are relevant issues because high-growth entrepreneurship has the potential to raise people out of poverty, encourage innovation, create jobs, reduce unemployment, make markets more competitive, and enhance economic growth. Finally, future research should focus on developing economies because there has been little formal investigation of the relationship between entrepreneurship and income inequality in developing countries (Naudé, 2010). These extensions of this study are left for future research.

About author: Antonio Lecuna is an assistant professor in the School of Business and Economics at Universidad del Desarrollo. His research interests are entrepreneurship, institutions, and Latin American Studies. Recent publications include 'Corruption and Size Decentralization' Journal of Applied Economics, 20I2) and 'From Chavismo to a Democratic Left in Venezuela' (Dissent, 20I3).

\section{About author}

Antonio Lecuna is an assistant professor in the School of Business and Economics at Universidad del Desarrollo. His research interests are entrepreneurship, institutions, and Latin American Studies. Recent publications include 'Corruption and Size Decentralization' (Journal of Applied Economics, 2012) and 'From Chavismo to a Democratic Left in Venezuela' (Dissent, 20I3). 


\section{References}

ACS, Z., Amorós, J.E. (2008). Entrepreneurship and competitiveness dynamics in Latin America. Small Business Economics, 3I (3), 305-322. DOI: http://dx.doi.org/|0.1007/s I I /87008-9133-y.

ALESINA A, Di Tella, R., MacCulloch, R. (2004). Inequality and happiness: Are Europeans and Americans different? Journal of Public Economics, 88(9-10), 2009-2042. DOI: http:// dx.doi.org//0.3386/w8/ 98.

AMORÓS,J.E. (20II).The Global Entrepreneurship Monitor project (GEM): a Latin-American context approach.Academia, Revista Latinoamericana de Administración, 46(I), I-I5. Available at: http://www.redalyc.org/pdf/7/6/7/617238002. pdf.

AMORÓS, J.E., Cristi, O. (2008). Entrepreneurship and competitiveness development: a longitudinal analysis of Latin American countries. International Entrepreneurship and Management Journal, 4(4), 38I-399. DOI: http://dx.doi. org/| 0.1007/s | | 365-008-0082-3.

BAPUJI, H., Riaz, S. (20I3). Economic inequality and management. Human Relations, 66(2), 299-303. DOI: http://dx.doi. org/I0.1 I77/00I87267/3478562.

BECKER, G., Tomes, N. (1979). An equilibrium theory of the distribution of income and intergenerational mobility. Journal of Political Economy, 87(6), I I53-I I89. DOI: http:// dx.doi.org/I0.1086/26083I.

BEDNARZIK, R.W. (2000). The role of entrepreneurship in U.S. and European job growth. Monthly Labor Review, I23(7), 3-16. Available at: http://www.bls.gov/opub/mlr/2000/07/artIfull.pdf.

BLANCHFLOWER, D., Oswald, A. (1998). What makes an entrepreneur? Journal of Labor Economics, 16(I), 26-60. DOI: http://dx.doi.org//0.1086/209881.

BOSMA. N., Coduras, A., Litovsky, Y., Seaman, J. (2012). GEM Manual: a report on the design, data and quality control of the Global Entrepreneurship Monitor. Babson College, Babson Park; Universidad del Desarollo, Santiago; Universiti Tun Abdul Razak, Kuala Lumpur; Global Entrepreneurship Research Association, London.

CABANA-VILLCA, R., Cortes-Castillo, I., Plaza-Pasten, D., Castillo-Vergara, M., Alvarez-Marin, A. (2013). Análisis de las capacidades emprendedoras potenciales y efectivas en alumnos de centros de educación superior. Journal of Technology Management and Innovation. 8(I), 65-75. DOI: http://dx.doi. org/I0.4067/s07/ 8-272420I3000I00007.
FAIRLIE R, Krashinsky, H.A. (20I2). Liquidity constraints, household wealth, and entrepreneurship revisited. Review of Income and Wealth, 58(2), 279-306. DOI: http://dx.doi. org/I0.I I I I/j. I475-499I.20I I.0049I.x.

FREEMAN, S. (1996). Equilibrium income inequality among identical agents. Journal of Political Economy, I04(5), I047I064. DOI: http://dx.doi.org//0.1086/26205I.

GALOR, O., Zeira, J. (1993). Income distribution and macroeconomics. Review of Economic Studies, 60(I), 35-52. DOI: http://dx.doi.org// 0.2307/22978 I I

GENTRY, W.M., Hubbard, G. (2004). Entrepreneurship and household saving. Advances in Economic Analysis \& Policy, 4(I), I538-0637. DOI: http://dx.doi.org/I0.2202/I5380637.1053.

GHATAK, M., Jiang, N. (2002). A simple model of inequality, occupational choice and development. Journal of Development Economics, 69, 205-226. DOI: http://dx.doi. org/l0.1016/s0304-3878(02)00059-7.

GUJARATI, D., Porter, D. (20I0). Essentials of Econometrics. McGraw Hill, New York.

HINOJOSA MARTÍNEZ, S., Albornoz Pardo, C. (20I3). Ganas de emprender $y$ felicidad: un estudio exploratorio a partir del Global Entrepreneurship Monitor en Chile. Journal of Technology Management and Innovation. 8(I), 76-89. DOI: http://dx.doi.org//0.4067/s07/8-27242013000100008.

HOLTZ-EAKIN, D., Joulfaian, D., Rosen, H.S. (I994a). Sticking it out: Entrepreneurial survival and liquidity constraints. Journal of Political Economy, I02(I), 53-75. DOI: http:// dx.doi.org/I0.1086/26192I.

HOLTZ-EAKIN, D., Joulfaian, D., Rosen, H.S. (1994b). Entrepreneurial decisions and liquidity constraints. RAND Journal of Economics, 25(2), 334-347. DOI: http://dx.doi. org// $0.2307 / 2555834$.

KIMHI,A. (2010). Entrepreneurship and income inequality in southern Ethiopia. Small Business Economics, 34(I), 8I-9I. DOI: http://dx.doi.org//0.1007/s | | |87-009-9|96-4.

KLAPPER, L., Love, I. (2010). The impact of the financial crisis on new firm registration. Working Paper No. 5444. World Bank Policy Research,Washington. DOI: http://dx.doi. org/I0.1596/18I3-9450-5444.

KRAUS S., Coen Rigtering, J.P., Hughes, M., Hosman,V. (2012). Entrepreneurial orientation and the business performance of SMEs: a quantitative study from the Netherlands. Review of Managerial Science, 6(2), 16I-182. DOI: http://dx.doi. org/| 0.1007/s I I846-0 I I-0062-9.

ISSN: 07 I8-2724. (http://www.jotmi.org) 
KREUTZMANN, H. (2008). Dividing the world: conflict and inequality in the context of growing global tension. Third World Quarterly, 29(4), 675-689. DOI: http://dx.doi. org/I0.1080/0I436590802052433.

LJUNGQVIST, L. (1993). Economic Underdevelopment: The case of missing market for human capital. Journal of Development Economics, 40, 219-239. DOI: http://dx.doi. org// 0.1016/0304-3878(93)90084-z.

LOURY, G. (I98I). Intergenerational transfers and the distribution of earnings. Econometrica, 49(4), 843-867. DOI: http://dx.doi.org//0.2307//9/2506.

MARQUARDT DW (1970) Generalized inverses, ridge regression, biuased linear estimation, and nonlinear regression. Technometrics, (I2): 59I-6/3. DOI: http://dx.doi. org// $0.2307 / / 267205$.

MARQUARDT, D.W. (1987). Collinearity and least squares regression: Comment. Statistical Science, 2(I), 84-85. DOI: http://dx.doi.org/I0.1214/ss/II 177013440.

MASON, C., Perreault, W.D. (199I). Collinearity, power, and interpretation of multiple regression analysis. Journal of Marketing Research, 28(3): 268-280. DOI: http://dx.doi. org//0.2307/3 I72863.

MEH, C.A. (2005). Entrepreneurship, wealth inequality, and taxation. Review of Economic Dynamics, 8(3), 688-719. DOI: http://dx.doi.org//0.1016/j.red.2005.03.00I.

NAUDÉ,W. (2010). Entrepreneurship, developing countries, and development economics: new approaches and insights. Small Business Economics, 34(I), I-12. DOI: http://dx.doi. org/|0.1007/s | | |87-009-9|98-2.

O'BRIEN, R.M. (2007). A caution regarding rules of thumb for variance inflation factors. Quality and Quantity, 4I(5) 673-690. DOI: http://dx.doi.org//0.1007/s III35-006-90|8-6.

OECD (1998). Fostering Entrepreneurship. Organization for Economic Co-operation and Development, Paris. DOI: http://dx.doi.org//0.1787/9789264/637/3-en.

QUADRINI, V. (1999). The importance of entrepreneurship for wealth concentration and mobility. Review of Income and Wealth, 45(I), I-19. DOI: http://dx.doi. org//0.1 I I I/j. I475-499I.1999.tb00309.x.

SCHUMPETER, J.A. (1934). The Theory of Economic Development. Harvard University Press, Cambridge (MA).
SHANE, S. (2009). Why encouraging more people to become entrepreneurs is bad public policy. Small Business Economics, 33(2), |4|-|49. DOI: http://dx.doi.org//0.1007/s I I /87009-92I5-5.

STATACORP (2009). Stata: Longitudinal Data/Panel Data Reference Manual. (Release II). StataCorp LP, College Station (TX).

TAMVADA, J.P. (2010). Entrepreneurship and welfare. Small Business Economics, 34(I), 65-79. DOI: http://dx.doi. org/|0.1007/s I | |87-009-9|95-5.

UNDP. Available at http://hdrstats.undp.org/en/indicators/67l06.html

UNU-WIDER. Available at http://www.wider.unu.edu/research/Database/en_GB/wiid/

VAN STEL, A., Carree, M.,Thurik, R. (2005). The effect of entrepreneurship on national economic growth. Small Business Economics, 24(3), 3I I-32 I. DOI: http://dx.doi.org/I0.1007/ sll|87-005-1996-6.

WHITE, H. (1980). A heteroskedasticity-consistent covariance matrix estimator and a direct test for heteroskedasticity. Econometrica, 48(4), 8I7-838. DOI: http://dx.doi. org//0.2307/19/2934.

WORLD BANK (2010). Entrepreneurship Snapshots 2010: Measuring the Impact of the Financial Crisis on New Business Registration. The World Bank Group, Washington. DOI: http://dx.doi.org//0.1596/978-0-82/3-8476-3.

WORLD FACTBOOK. Available at https://www.cia.gov/library/publications/the-world-factbook/fields/2I $72 . h t m l$. 


\section{Appendixes}

\begin{tabular}{|c|c|c|c|c|c|c|c|c|c|c|c|c|c|c|c|c|c|}
\hline \multirow{2}{*}{ CIA } & \multicolumn{2}{|l|}{2004} & \multicolumn{3}{|c|}{2005} & \multicolumn{3}{|c|}{2006} & \multicolumn{3}{|c|}{2007} & \multicolumn{3}{|c|}{2008} & \multicolumn{3}{|c|}{2009} \\
\hline & UNDP & WIDER & $\mathrm{CIA}$ & UNDP & WIDER & $\mathrm{CIA}$ & UNDP & WIDER & CIA & UNDP & WIDER & $\mathrm{CIA}$ & UNDP & WIDER & CIA & UNDP & WIDER \\
\hline Argentina & & 51 & 49 & & 50 & 48 & & 48 & 47 & & & 46 & & & 46 & 46 & \\
\hline Australia & & 29 & & & & & 31 & & & & & & & & & & \\
\hline Austria & & 26 & & & 26 & & & 25 & & 26 & & & & & & & \\
\hline Belgium & & 26 & & 28 & 28 & & & 28 & & & & & & & & & \\
\hline Bosnia and Herzeg & govina & & & & 36 & & & & 36 & 36 & & & & & & & \\
\hline Brazil & & 57 & 57 & & 56 & 57 & & & 56 & & & 55 & & & 55 & & \\
\hline Canada & & & & 32 & & & & & & & & & & & & & \\
\hline Chile & & & & & & 52 & & & & & & & & & 52 & 52 & \\
\hline Colombia & & 56 & 56 & & & 59 & & & 59 & & & 57 & & & 57 & & \\
\hline Croatia & & & & & 29 & & & & & & & 34 & & & & 27 & \\
\hline Czech Republic & & & & & 26 & & & 25 & & & 27 & & & & & 31 & \\
\hline Denmark & & 24 & & & 24 & & & 24 & & & & & & & & & \\
\hline Dominican Republi & & 51 & 51 & & 51 & 52 & & 52 & 49 & 48 & & 49 & & & 49 & & \\
\hline Egypt & & 34 & 32 & & & & & & & & & 31 & & & & & \\
\hline Finland & & 25 & & & 26 & & & 26 & & & & & 27 & & & & \\
\hline France & & 28 & & & 28 & & & 27 & & & & & 33 & & & & \\
\hline Germany & & 28 & & & 26 & & 27 & 27 & & & & & & & & & \\
\hline Greece & & 33 & & 33 & 33 & & & 34 & & & & & & & & & \\
\hline Hong Kong & & & & & & & & & & 53 & & & & & & & \\
\hline Hungary & & 27 & & & 28 & & & 26 & 31 & & & & & & & 25 & \\
\hline Iceland & & 24 & & 25 & 25 & & 28 & 26 & & & & & & & & & \\
\hline Indonesia & & & 34 & 39 & 39 & & & & & & & & & & & 37 & \\
\hline Ireland & & 32 & & & 32 & & & 32 & & & & & & & & & \\
\hline Israel & & & & & & & & & & & & & 39 & & & & \\
\hline Italy & & 33 & & & 33 & & 32 & 32 & & & & & & & & & \\
\hline Jamaica & 46 & & & & 46 & & & & & & & & & & & & \\
\hline Japan & & & & & & & & & & & & & 38 & & & & \\
\hline Jordan & & & & & & 38 & & & & 40 & & 34 & & & & & \\
\hline Kazakhstan & & 37 & & & 42 & 31 & & 41 & 31 & & & 29 & & & 29 & 28 & \\
\hline Korea & & 32 & & & & & & & & & & & & & & & \\
\hline Latvia & & & & & 39 & & & 39 & 36 & & & 37 & & & & & \\
\hline Malaysia & & 40 & & & & & & & 46 & & & & & & 46 & 46 & \\
\hline Mexico & & 50 & & & 51 & 48 & & & & & & 48 & 52 & & & & \\
\hline Morocco & & & & & & & & & 41 & 41 & & & & & & & \\
\hline Netherlands & & & & & 27 & & & 26 & & 31 & & & & & & & \\
\hline New Zealand & & 34 & & & & & & & & & & & & & & & \\
\hline Norway & & 25 & & & 28 & & & 30 & & & & & 25 & & & & \\
\hline Panama & & 55 & 54 & & & 55 & & & & & & & & & 52 & & \\
\hline Peru & & 48 & 51 & 51 & 48 & 51 & & & 52 & & & 49 & & & 49 & & \\
\hline Philippines & & & & & & 44 & 46 & & & & & & & & 43 & & \\
\hline Poland & & 35 & 35 & & 37 & 34 & 34 & 34 & 34 & & & 34 & & & 34 & & \\
\hline Portugal & & 38 & & & 38 & & & 38 & & 39 & & & & & & & \\
\hline Romania & & 36 & 32 & & 36 & 32 & & 36 & 32 & & & 31 & & & 30 & & \\
\hline Russia & & 47 & 38 & & 45 & 42 & & 45 & 44 & & & 42 & & & 40 & & \\
\hline Serbia & & 33 & 33 & & 31 & 30 & & 35 & 29 & & & 28 & 28 & & 28 & & \\
\hline Singapore & & & & & & & & & & & & & 48 & & & & \\
\hline Slovenia & 24 & 30 & & & 28 & & & 31 & & & & & 28 & & & & \\
\hline South Africa & & & & 65 & & 67 & & & & & & & & & 63 & & \\
\hline Spain & & 31 & & 32 & 32 & & & 31 & & & & & & & & & \\
\hline Sweden & & 23 & & 23 & 23 & & & 23 & & & & & & & & & \\
\hline Thailand & & & & & & 42 & & & & & & 41 & & & 40 & 54 & \\
\hline Turkey & & & 43 & & & 40 & & & 39 & & & 39 & & & & & \\
\hline United Kingdom & & & & 34 & 34 & & & 32 & & & & & & & & & \\
\hline Uruguay & & 46 & 46 & & 45 & 47 & & & 48 & & & 46 & & & 46 & & \\
\hline
\end{tabular}

Table A I. Gini data

ISSN: 07 I 8-2724. (http://www.jotmi.org)

Journal of Technology Management \& Innovation (c) Universidad Alberto Hurtado, Facultad de Economía y Negocios. 


\begin{tabular}{|c|c|c|c|c|c|c|c|c|}
\hline $\begin{array}{l}\text { Very High Human } \\
\text { Development }\end{array}$ & 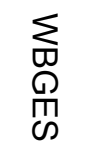 & m & $\begin{array}{l}\text { High Human } \\
\text { Development }\end{array}$ & 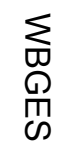 & 䎡 & $\begin{array}{l}\text { Medium Human } \\
\text { Development }\end{array}$ & 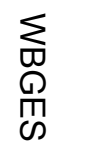 & 尚 \\
\hline Argentina & 0.56 & 13.04 & Bosnia \& Herz. & 0.71 & 6.73 & Dominican Rep. & 2.13 & 18.21 \\
\hline Australia & 6.33 & 12.07 & Brazil & 2.10 & 12.75 & Egypt & 0.13 & 13.11 \\
\hline Austria & 0.64 & 3.86 & Colombia & 1.02 & 23.07 & Indonesia & 0.17 & 19.28 \\
\hline Belgium & 4.15 & 3.27 & Jamaica & 1.12 & 18.92 & Jordan & 0.59 & 14.25 \\
\hline Canada & 8.00 & 8.43 & Kazakhstan & 2.88 & 9.36 & Morocco & 0.98 & 15.75 \\
\hline Chile & 2.18 & 12.31 & Malysia & 2.60 & 7.75 & Philippines & 0.23 & 20.44 \\
\hline Croatia & 2.95 & 6.48 & Mexico & 0.62 & 8.09 & South Africa & 1.13 & 5.90 \\
\hline Czech Rep. & 2.53 & 7.85 & Panama & 3.04 & 9.59 & Thailand & 0.64 & 20.94 \\
\hline Denmark & 6.29 & 4.81 & Peru & 2.13 & 30.58 & & & \\
\hline Finland & 3.20 & 5.63 & Romania & 5.75 & 4.34 & & & \\
\hline France & 3.14 & 4.82 & Russian Fed. & 4.03 & 3.73 & & & \\
\hline Germany & 1.18 & 4.51 & Serbia & 2.10 & 7.02 & & & \\
\hline Greece & 0.94 & 7.42 & Turkey & 0.99 & 5.87 & & & \\
\hline Hong Kong & 15.25 & 5.52 & Uruguay & 3.08 & 12.21 & & & \\
\hline Hungary & 4.46 & 5.81 & & & & & & \\
\hline Iceland & 14.61 & 11.58 & & & & & & \\
\hline Ireland & 5.97 & 8.14 & & & & & & \\
\hline Israel & 4.66 & 6.15 & & & & & & \\
\hline Italy & 1.89 & 4.35 & & & & & & \\
\hline Japan & 1.43 & 3.27 & & & & & & \\
\hline Korea, Rep. & 1.56 & 8.50 & & & & & & \\
\hline Latvia & 5.88 & 6.94 & & & & & & \\
\hline Netherlands & 2.95 & 5.41 & & & & & & \\
\hline New Zealand & 22.85 & 16.12 & & & & & & \\
\hline Norway & 4.84 & 8.18 & & & & & & \\
\hline Poland & 0.49 & 8.83 & & & & & & \\
\hline Portugal & 4.01 & 6.37 & & & & & & \\
\hline Singapore & 6.55 & 5.93 & & & & & & \\
\hline Slovenia & 3.49 & 4.69 & & & & & & \\
\hline Spain & 4.57 & 6.30 & & & & & & \\
\hline Sweden & 4.04 & 3.84 & & & & & & \\
\hline United Kingdom & 9.25 & 5.90 & & & & & & \\
\hline
\end{tabular}

Table A2. Statistical sample

Note:The information reflects the available data for the average period of 2004-2009. Countries are subdivided in categories based on the Human Development Index (HDI) value determined by the United Nations Development Programme

(UNDP). Countries are listed in alphabetical order.

ISSN: 07 I8-2724. (http://www.jotmi.org)

Journal of Technology Management \& Innovation (c) Universidad Alberto Hurtado, Facultad de Economía y Negocios. 


\begin{tabular}{|c|c|c|c|c|c|c|c|c|c|c|c|}
\hline & 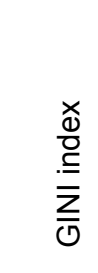 & 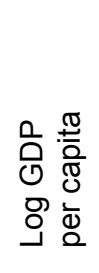 & 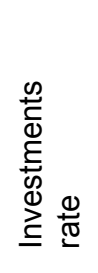 & 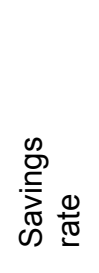 & 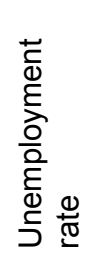 & 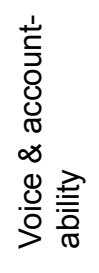 & 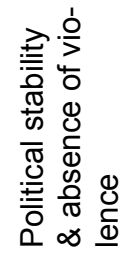 & 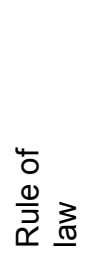 & 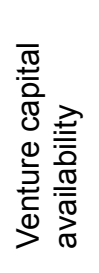 & 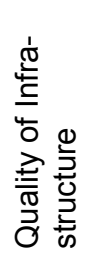 & $\begin{array}{l}\overrightarrow{\frac{t}{d}} \\
\frac{0}{0} \\
\frac{0}{0} \\
\frac{0}{2}\end{array}$ \\
\hline GINI index & 1 & & & & & & & & & & \\
\hline $\begin{array}{l}\text { Log GDP } \\
\text { per capita }\end{array}$ & $-.60^{*}$ & 1 & & & & & & & & & \\
\hline $\begin{array}{l}\text { Investments } \\
\text { rate }\end{array}$ & $-.27^{*}$ & -.10 & 1 & & & & & & & & \\
\hline $\begin{array}{l}\text { Savings } \\
\text { rate }\end{array}$ & -.14 & $.11^{*}$ & $.18^{*}$ & 1 & & & & & & & \\
\hline $\begin{array}{l}\text { Unemployment } \\
\text { rate }\end{array}$ & $.31^{*}$ & $-.48^{*}$ & $-.12^{*}$ & $-.46^{*}$ & 1 & & & & & & \\
\hline $\begin{array}{l}\text { Voice \& account- } \\
\text { ability }\end{array}$ & $-.48^{*}$ & $.80^{*}$ & $-.16^{*}$ & $-.19^{*}$ & $-.25^{*}$ & 1 & & & & & \\
\hline $\begin{array}{l}\text { Political stability \& } \\
\text { absence of violence }\end{array}$ & $-.60^{*}$ & $.75^{\star}$ & .05 & $.11^{*}$ & $-.36^{*}$ & $.71^{*}$ & 1 & & & & \\
\hline $\begin{array}{l}\text { Rule of } \\
\text { law }\end{array}$ & $-.62^{*}$ & $.87^{*}$ & $-.12^{*}$ & $.15^{*}$ & $-.46^{*}$ & $.78^{\star}$ & $.78^{*}$ & 1 & & & \\
\hline $\begin{array}{l}\text { Venture capital avail- } \\
\text { ability }\end{array}$ & $-.40^{*}$ & $.63^{*}$ & -.02 & $.37^{*}$ & $-.45^{*}$ & $.45^{\star}$ & $.48^{*}$ & $.73^{*}$ & 1 & & \\
\hline $\begin{array}{l}\text { Quality of Infrastruc- } \\
\text { ture }\end{array}$ & $-.34^{*}$ & $.72^{*}$ & $-.17^{\star}$ & $.27^{*}$ & $-.43^{*}$ & $.50^{*}$ & $.62^{*}$ & $.84^{*}$ & $.68^{*}$ & 1 & \\
\hline $\begin{array}{l}\text { Property } \\
\text { rights }\end{array}$ & $-.28^{*}$ & $.73^{*}$ & $-.15^{*}$ & $.15^{*}$ & $-.41^{*}$ & $.61^{*}$ & $.65^{*}$ & $.89^{\star}$ & $.75^{\star}$ & $.87^{*}$ & 1 \\
\hline
\end{tabular}

Table A3. Pairwise correlation matrix of explanatory variables. Note: Significant at the $5 \%$ level. 


\begin{tabular}{|c|c|c|c|c|c|c|}
\hline \multirow{3}{*}{$\begin{array}{l}\text { Dependent Variables: } \\
\text { WBGES \& TEA }\end{array}$} & \multicolumn{2}{|c|}{1} & \multicolumn{2}{|c|}{ II } & \multicolumn{2}{|c|}{ III } \\
\hline & \multicolumn{2}{|c|}{$\begin{array}{l}\text { Low } \\
\text { multiculinearity }\end{array}$} & \multicolumn{2}{|c|}{$\begin{array}{l}\text { Endogeneity test: } \\
\text { Low multiculinearity }\end{array}$} & \multicolumn{2}{|c|}{$\begin{array}{c}\text { Endogeneity test: } \\
\text { Whole-set }\end{array}$} \\
\hline & WBGES & TEA & WBGES & TEA & WBGES & TEA \\
\hline GINI index & $\begin{array}{c}0.12 \\
(2.81)^{\star \star *}\end{array}$ & $\begin{array}{c}0.002 \\
(1.84)^{*}\end{array}$ & $\begin{array}{c}0.15 \\
(2.91)^{\star \star \star}\end{array}$ & $\begin{array}{c}0.004 \\
(2.97)^{\star \star \star}\end{array}$ & $\begin{array}{c}0.19 \\
(3.26)^{\star \star *}\end{array}$ & $\begin{array}{c}0.003 \\
(2.75)^{\star *}\end{array}$ \\
\hline Log GDP per capita & $\begin{array}{c}2.85 \\
(1.56)\end{array}$ & $\begin{array}{c}-0.11 \\
(-2.98)^{\star * *}\end{array}$ & $\begin{array}{c}2.93 \\
(1.22)\end{array}$ & $\begin{array}{c}-0.16 \\
(-3.70)^{\star \star *}\end{array}$ & $\begin{array}{c}2.85 \\
(1.19)\end{array}$ & $\begin{array}{c}-0.17 \\
(-3.87)^{\star \star *}\end{array}$ \\
\hline Investment rate & $\begin{array}{c}19.96 \\
(2.56)^{\star \star}\end{array}$ & $\begin{array}{c}0.09 \\
(0.58)\end{array}$ & $\begin{array}{c}24.04 \\
(2.42)^{\star *}\end{array}$ & $\begin{array}{c}0.25 \\
(1.58)\end{array}$ & $\begin{array}{c}22.24 \\
(2.20)^{* *}\end{array}$ & $\begin{array}{c}0.29 \\
(1.93)^{\star}\end{array}$ \\
\hline Savings rate & $\begin{array}{c}-20.79 \\
(-3.24)^{\star \star *}\end{array}$ & $\begin{array}{l}-0.04 \\
(-0.31)\end{array}$ & $\begin{array}{c}-21.58 \\
(-2.89)^{\star \star *}\end{array}$ & $\begin{array}{c}0.05 \\
(0.48)\end{array}$ & $\begin{array}{c}-26.06 \\
(-3.23)^{\star \star *}\end{array}$ & $\begin{array}{c}0.11 \\
(0.92)\end{array}$ \\
\hline Unemployment rate & $\begin{array}{c}-25.73 \\
(-2.27)^{\star \star}\end{array}$ & $\begin{array}{c}-0.36 \\
(-1.71)^{*}\end{array}$ & $\begin{array}{c}-22.07 \\
(-2.19)^{\star *}\end{array}$ & $\begin{array}{l}-0.21 \\
(-1.13)\end{array}$ & $\begin{array}{c}-24.14 \\
(-2.36)^{\star \star}\end{array}$ & $\begin{array}{l}-0.14 \\
(-0.71)\end{array}$ \\
\hline Voice \& accountability & $\begin{array}{c}-1.47 \\
(-1.70)^{*}\end{array}$ & $\begin{array}{c}0.04 \\
(1.98)^{*}\end{array}$ & $\begin{array}{l}-1.31 \\
(-1.16)\end{array}$ & $\begin{array}{c}0.04 \\
(2.07)^{* *}\end{array}$ & $\begin{array}{l}-2.13 \\
(-1.57)\end{array}$ & $\begin{array}{c}0.07 \\
(2.70)^{\star \star}\end{array}$ \\
\hline Political stability \& absence of violence & $\begin{array}{c}1.21 \\
(1.75)^{\star}\end{array}$ & $\begin{array}{l}-0.01 \\
(-0.83)\end{array}$ & $\begin{array}{c}1.31 \\
(1.36)\end{array}$ & $\begin{array}{l}-0.02 \\
(-1.06)\end{array}$ & $\begin{array}{c}0.94 \\
(0.95)\end{array}$ & $\begin{array}{l}-0.01 \\
(-1.07)\end{array}$ \\
\hline Rule of law & & & & & $\begin{array}{c}2.72 \\
(1.32)\end{array}$ & $\begin{array}{c}-0.07 \\
(-1.73)^{*}\end{array}$ \\
\hline Venture capital availability & $\begin{array}{c}2.09 \\
(3.02)^{\star * *}\end{array}$ & $\begin{array}{c}0.01 \\
(1.05)\end{array}$ & $\begin{array}{c}2.95 \\
(3.26)^{\star \star \star}\end{array}$ & $\begin{array}{c}0.03 \\
(1.97)^{\star}\end{array}$ & $\begin{array}{c}3.14 \\
(3.01)^{* * *}\end{array}$ & $\begin{array}{c}0.03 \\
(2.19)^{* *}\end{array}$ \\
\hline Quality of overall infrastructure & $\begin{array}{l}-0.33 \\
(-0.67)\end{array}$ & $\begin{array}{l}-0.01 \\
(-0.63)\end{array}$ & $\begin{array}{l}-0.59 \\
(-1.02)\end{array}$ & $\begin{array}{c}0.01 \\
(1.05)\end{array}$ & $\begin{array}{l}-0.45 \\
(-0.54)\end{array}$ & $\begin{array}{c}0.01 \\
(1.19)\end{array}$ \\
\hline Property Rights & & & & & $\begin{array}{l}-1.96 \\
(-1.32)\end{array}$ & $\begin{array}{c}0.03 \\
(1.45)\end{array}$ \\
\hline Adjusted $R$-squared & $60 \%$ & $53 \%$ & $60 \%$ & $73 \%$ & $63 \%$ & $76 \%$ \\
\hline$N$ & 102 & 83 & 80 & 62 & 80 & 62 \\
\hline
\end{tabular}

Table A4. Multiculinearity and Endogeneity tests, panel data 2004-2009. (Between-estimates linear regression models, OLS)

Notes: Heteroskedasticity-consistent t-ratios (White, 1980) in parentheses.

*** Significant at $1 \%$; **significant at $5 \%$; *significant at $10 \%$.

Endogeneity is alleviated by lagging predictor variables I year.

ISSN: 07 I8-2724. (http://www.jotmi.org)

Journal of Technology Management \& Innovation (c) Universidad Alberto Hurtado, Facultad de Economía y Negocios. 